\title{
BUILDING IMMUNITY AND INVESTING VALUE OF PANCASILA THROUGH ARCHERY COVID-19 IN PANDEMIC TIME
}

\author{
Yudik Prasetyo \\ Ilmu Keolahragaan, Fakultas Ilmu Keolahragaan, Universitas Negeri Yogyakarta. \\ Jl. Colombo No. 1, Karangmalang Depok, Sleman, Yogyakarta, Indonesia \\ yudik@uny.ac.id
}

\begin{abstract}
Increasingly sophisticated technology, such as the emergence of online games, will have a negative impact on children in their active awareness. This study aims to determine the immunity and inculcation of Pancasila values through archery. This research is a mixed-method with a combination of quantitative and qualitative approaches. The population used was all children who took part in archery training in the West Sleman region, with a total sample of 50 people. Immunity data collection techniques using questionnaires, and Pancasila values using observation, in-depth interviews, and documentation. The results showed that archery was practiced by children 3 times per week on a regular basis, while still meeting health protocols, the basic archery techniques used, archery distances of $15 \mathrm{~m}, 20 \mathrm{~m}$, and $25 \mathrm{~m}$ on the immune response of 48 children ( $96 \%$ ) is in a good category, 2 children $(4 \%)$ are in enough category, while providing an understanding of the values of Pancasila when archery is carried out provides strengthening and perceived benefits such as (1) the awareness of the child praying before starting archery practice, (2) help each other when there is a missing arrow, and the archery remains in the shooting line, (3) work hand in hand and have a strong spirit of unity, (4) convey opinions to the Coach or Referee according to the regulations, (5) take turns equitably in archery according to the time provided. Based on the results of this study, it can be interpreted that archery can build immunity and provide an understanding of the values of Pancasila so that it is not only physical but also the noble values of Pancasila contained in it.
\end{abstract}

Keywords: immunity, Pancasila values, archery

\section{MEMBANGUN IMUNITAS DAN MENANAMKAN NILAI-NILAI PANCASILA MELALUI OLAHRAGA PANAHAN DI MASA PANDEMI COVID-19}

\begin{abstract}
Abstrak
Teknologi yang semakin canggih seperti banyak munculnya game online, akan memberikan dampak negatif bagi anak-anak dalam kesadaran aktif bergerak. Penelitian ini bertujuan untuk mengetahui imunitas dan penanaman nilai-nilai Pancasila melalui olahraga panahan. Penelitian ini merupakan penelitian campuran (mixed methods) dengan perpaduan pendekatan kuantitatif dan pendekatan kualitatif. Populasi yang digunakan adalah semua anak-anak yang ikut latihan panahan di Wilayah Sleman Barat, dengan jumlah sampel sebanyak 50 orang. Teknik pengambilan data imunitas dengan angket, dan nilai-nilai Pancasila menggunakan observasi, wawancara yang mendalam, dan dokumentasi. Hasil penelitian menunjukan bahwa olahraga panahan yang dilakukan oleh anak-anak sebanyak 3 kali per minggu secara teratur, dengan tetap memenuhi protokol kesehatan, teknik dasar panahan yang digunakan, jarak memanah $15 \mathrm{~m}, 20 \mathrm{~m}$, dan $25 \mathrm{~m}$ pada respon imun sejumlah 48 anak (96\%) dalam kategori baik, 2 anak (4\%) kategori cukup, sedangkan pemberian pemahaman nilainilai Pancasila pada saat olahraga panahan dilakukan memberikan penguatan dan manfaat yang dirasakan seperti: (1) kesadaran anak berdoa sebelum mulai latihan panahan, (2) saling membantu saat ada anak panah yang hilang, dan memanah tetap berada di shooting line, (3) saling bahumembahu dan memiliki jiwa persatuan yang kuat, (4) menyampaikan pendapat kepada Pelatih atau Wasit sesuai peraturan, (5) bergantian secara adil dalam memanah sesuai waktu yang disediakan.
\end{abstract}


Berdasarkan hasil penelitian tersebut dapat diartikan bahwa olahraga panahan dapat membangun imunitas dan memberikan pemahaman pada nilai-nilai Pancasila, sehingga tidak hanya fisik saja yang diperoleh tetapi juga nilai-nilai luhur Pancasila yang terkandung di dalamnya.

Kata Kunci : imunitas, nilai-nilai Pancasila, panahan

\section{PENDAHULUAN}

Pandemi COVID-19 telah membuat dunia yang bergerak cepat ini terhenti. Dampak dari pandemi ini sangat besar dan satu-satunya strategi untuk mengekang penyebarannya yang cepat adalah dengan mengikuti jarak sosial. Penguncian yang diberlakukan, yang mengakibatkan penutupan kegiatan bisnis, tempat umum, pusat kebugaran dan aktivitas, dan kehidupan sosial secara keseluruhan, telah menghambat banyak aspek kehidupan masyarakat termasuk aktivitas kebugaran rutin para penyuka kebugaran, sehingga mengakibatkan berbagai masalah psikologis, dan masalah kebugaran dan kesehatan yang serius (Kaur Harleen, 2020: 1). Pada masa pandemi covid-19, kegiatan online menggunakan laptop dan handphone menjadi dominan dilakukan oleh anak-anak, baik dalam proses pembelajaran maupun proses bermain untuk mengisi waktu luang. Orang tua sebagai pendamping di rumah perlu mengontrol aktivitas yang dilakukan oleh anak-anak. Oleh karena, apabila pendampingan yang dilakukan tidak bagus maka anak-anak semakin ketergantungan pada penggunaan Android.

Pancasila adalah kumpulan nilai-nilai kebaikan, susunan nilai-nilai moral, dan himpunan nilai-nilai etika. Olahraga panahan hubungannya dengan Pancasila merefleksikan suatu permainan yang didasarkan pada nilai-nilai sportivitas dan fairness. Selain sikap sportif dan fair, nilai-nilai Pancasila dalam panahan harus tercermin pada perilaku para pemanah. Pemanah yang bagus harus dapat mengendalikan emosi, tidak mudah terprovokasi, dan tidak mudah mengeluarkan kata-kata ejekan. Pada dasarnya olahraga panahan, tidak hanya mengandung manfaat dalam membangun imunitas, tetapi juga menumbuhkembangkan nilai-nilai Pancasila yang sangat bermanfaat dalam kehidupan. Secara fungsional olahraga panahan berfungsi menyehatkan tubuh, sedangkan pada dimensi sosial, olahraga panahan dapat berperan dalam menanamkan nilai-nilai dan norma-norma kehidupan yang patut diamalkan dalam kehidupan.

Dalam bidang keolahragaan, nilai-nilai ini sangat penting mengingat bidang keolahragaan merupakan mikrokosmos yang mencerminkan atau merefleksikan tatanan masyarakat yang lebih luas. Nilai-nilai tersebut, terutama akan memberikan pengaruh dalam hal pembentukan watak dan karakter individu-individu, sekaligus mencerminkan masyarakatnya. Olahraga panahan semakin berkembang pesat, namun masih kurang dalam perhatian menggiatkan olahraga panahan dengan memasukan nilai-nilai Pancasila. Pada saat ini yang lebih mencengangkan adalah peralatan busur yang digunakan untuk memanah, disalahgunakan untuk melakukan aksi kriminal. Hal ini jelas bertentangan dengan nilai-nilai Pancasila.

Di beberapa sekolah, olahraga panahan mulai dimasukan sebagai ekstrakurikuler yang bisa dipelajari oleh siswa. Anak-anak yang mengikuti olahraga panahan di sekolah atau di Klub, sebelumnya lebih termotivasi belajar kearah keterampilannya, namun untuk mengimplementasikan nilai-nilai Pancasila masih jarang yang melakukan. Padahal kita ketahui bersama bahwa lambang PERPANI (Persatuan Panahan Indonesia) adalah berbentuk segi lima yang artinya berasaskan Pancasila. Menurut Suryo Ediyono (2016: 309) bahwa identifikasi simbol-simbol menunjukkan giat-giat yang memotivasi penanaman nilainilai Pancasila, mempersatukan, memelihara dan memperkuat persatuan bangsa, semangat penggerak bangsa dalam melaksanakan pembangunan nasional dan menyelesaikan masalahmasalah yang timbul dalam kehidupan bangsa. 
Olahraga panahan sekarang sudah diajarkan dari tingkat SD, SMP, SMA, sampai Perguruan Tinggi. Pada masa pandemi covid-19 ini, olahraga panahan menjadi salah satu alternatif bagi anak-anak untuk bergerak dan mengasah keterampilan. Keunggulan olahraga panahan yaitu dapat dilakukan secara perorangan, peralatan yang digunakan sesuai ukuranya masing-masing sehingga protokoler kesehatan tetap terjaga. Dengan diajarkan olahraga panahan tersebut, maka perlu sekali untuk bagaimana mengimplementasikan nilainilai Pancasila.

\section{Olahraga panahan dan relevansinya terhadap nilai-nilai pancasila dan kesehatan}

Olahraga panahan merupakan pelajaran yang mempunyai peranan penting yang harus dikuasai secara pengetahuan dan diaplikasikan secara tindakan. Olahraga panahan bukan sekedar mempelajari pengetahuan semata, tetapi juga mengajarkan nilai-nilai luhur landasan negara Indonesia yaitu Pancasila, yang dapat diterapkan dalam kehidupan nyata. Perilaku luhur, menghargai sesama, toleransi dan sikap saling memahami bukan lagi sebagai teori, namun hal ini harus menjadi sikap yang mendarah daging dan dilaksanakan dalam kehidupan. Dengan demikian, pelaksanaan hak dan kewajiban sebagai warga negara Indonesia yang cerdas, berakhlak mulia sesuai tuntunan agama dapat terwujudkan dengan baik. Olahraga panahan yang dilakukan berisi konsep keterampilan/teknik dasar memanah (stance, nocking, extend, drawing, anchoring, aiming, tighten, release, dan after hold), peraturan perlombaan panahan ronde nasional, baik nomor perorangan maupun beregu.

Nilai Pancasila harus dibangun dan diterapkan dalam berbagai bidang kehidupan, sehingga falsafah Pancasila tersebut menjadi bagian yang tidak terpisahkan dalam kehidupan berbangsa dan bernegara, termasuk dalam bidang olahraga. Olahraga bela diri seperti karate, pencak silat, maupun panahan memiliki sejarah dan falsafah yang berbeda, namun memiliki pemahaman yang sama yakni membangun jati diri dan membela kebenaran. "Pancasila merupakan landasan utama bangsa Indonesia. Nilai-nilai Pancasila, tetap menjadi bagian utama yang tidak bisa dipisahkan dalam ideologi nilai kebangsaan.

Pancasila pada saat ini semakin mendapatkan tantangan, sehingga perlu sekali dalam implementasi yang berkelanjutan kepada anak-anak sebagai generasi penerus bangsa. Berdasarkan realita yang ada dalam masyarakat, aplikasi sila-sila Pancasila jauh dari harapan. Banyaknya kerusuhan yang berlatar belakang SARA (suku, ras, dan antar golongan), adanya pelecehan terhadap hak asasi manusia, gerakan separatis, lunturnya budaya musyawarah, serta ketidakadilan dalam masyarakat membuktikan tidak aplikatifnya Pancasila. Adanya hal tersebut menjauhkan harapan terbentuknya masyarakat yang sejahtera, aman, dan cerdas yang diidamkan melalui Pancasila (Aminullah, 624). Olahraga panahan agar tidak disalahgunakan sebagai senjata untuk kriminalitas, maka solusi yang diharapkan adalah dengan para Pendidik atau Pelatih olahraga panahan saat mengajar teknik memanah, diharapkan juga memasukan nilai-nilai Pancasil. Hal ini apabila di implementasikan secara berkelanjutan kepada generasi muda akan memberikan manfaat yang luar dan manfaat yang positif yang didapatkan.

Desain induk pembangunan karakter bangsa (2010: 7) menyebutkan bahwa karakter bangsa merupakan "kualitas perilaku kolektif kebangsaan yang unik, baik tercermin dalam kesadaran, pemahaman, rasa karsa, dan perilaku berbangsa dan bernegara dari hasil olah pikir, olah hati, olah rasa dan karsa, serta olahraga seseorang atau sekelompok orang". Sehingga individu yang telah dijiwai oleh sila-sila Pancasila melaksanakan nilai-nilai berikut: 1) Karakter yang bersumber dari olah hati, antara lain beriman dan bertaqwa, jujur, amanah, adil, tertib, taat aturan, bertanggung jawab, berempati, berani, mengambil resiko, pantang menyerah, rela berkorban, dan berjiwa patriotik; 2) Karakter yang bersumber dari olah pikir antara lain cerdas, kritis, kreatif, inovatif, ingin tahu, produktif, berorientasi Ipteks dan reflektif; 3) Karakter yang bersumber dari olah raga antara lain: bersih, sehat, sportif, tangguh, andal, berdaya tahan, bersahabat, kooperatif, determinatif, kompetitif, ceria, dan 
gigih; 4) Karakter yang bersumber dari olah rasa dan karsa antara lain: kemanusiaan, saling menghargai, gotong-royong, kebersamaan, ramah, hormat, toleran, nasionalis, peduli, kosmopolit, mengutamakan kepentingan umum, cinta tanah air, bangga menggunakan bahasa, dan produk Indonesia, dinamis, kerja keras, dan beretos kerja. (Desain Induk Pembangunan Karakter Bangsa, 2010 dalam Prosiding Kongres Pancasila IV, 2012).

Membangun karakter bangsa sebenarnya sudah terpikirkan oleh bangsa Indonesia melalui para the founding father jauh sebelum bangsa Indoensia merdeka. Bung Karno amat sering menyampaikan pentingnya membangun karakter bangsa (nation character building). Awal rintisan membangun bangsa Indonesia sebelum sumpah pemuda 28 Oktober 1928 dalam lagu kebangsaan hasil gubahan WR Supratman Indonesia raya menyatakan bahwa Indonesia Raya dapat dibangun melalui membangun jiwanya. Simaklah bunyi syair lagu Indonesia Raya "bangunlah jiwanya, bangunlah badannya untuk Indonesia Raya". Syair lagu kebangsaan Indonesia Raya tersebut tidak cukup cuma dinyanyikaan melainkan ditindak lanjuti dengan aksi membangun bangsa ini mulai dari membangun Jiwa atau karakter Bangsanya. Namun, yang terjadi pada bangsa Indonesia dalam pembangunannya justru dimulai dan menitik beratkan pada aspek fisik material. Tidak aneh apabila hasilnya adalah lahir anak-anak bangsa yang berorientasi pada faktor fisik material, individualistis (Sutan Syahrir Zabda, 2016: 108-109).

Penelitian yang dilakukan oleh Ratnasari Putri Utami (2018: 556) bahwa pemanah jemparingan lebih mudah memberikan makna bagi kehidupan melalui pemahaman filosofi dalam setiap proses jemparingan. Jemparingan digunakan sebagai alat untuk mengajari para pemanah agar selalu meningkatkan kesadaran diri saat berlatih jemparingan. Namun, tidak semua pemanah jemparingan memahami filosofi jemparingan. Banyak diantara pemanah yang tidak menerapkan filosofi jemparingan, bahkan beberapa di antara pemanah justru memiliki sikap yang berlawanan dengan filosofi jemparingan. Kebiasaan yang terbangun dalam kegiatan jemparingan dapat diimplementasikan dalam kehidupan sehari-hari dalam rangka penerapan Kawruh Jiwa. Pada saat itu, pemanah jemparingan akan mampu mewujudkan kesadaran, meningkatkan kesadaran dimanapun, kapanpun, dalam setiap kondisi. Jemparingan dapat dilakukan oleh semua orang, pria dan wanita di segala usia, berbagai latar belakang, di luar agama dan kepercayaan. Nilai terpenting dari jemparingan adalah bagaimana senantiasa waspada dalam setiap kondisi. Sama halnya dengan jemparingan, nilai utama Kawruh Jiwa adalah bagaimana menjalani hidup dengan kesadaran dan perhatian penuh. Berdasarkan filosofi dari panahan jemparingan yang sudah dari jaman nenek moyang kita, memberikan gambaran bahwa panahan memiliki arti penting dalam kehidupan, sehingga anak-anak sebagai generasi bangsa apabila menerapkan dengan baik akan memberikan manfaat yang positif, dan nilai tersebut erat kaitannya dengan nilai-nilai Pancasila.

Tujuan utama olahraga bukan pembangunan fisik saja, melainkan juga pembangunan mental dan spiritual. Olahraga (lama) ialah merupakan suatu kegiatan yang dilakukan atas pilihan sendiri yang bermaksud menguatkan diri baik fisik maupun psikis tanpa mengharapkan suatu hasil materiil tetapi mengharapkan kenaikan prestasi. Olahraga (baru) ialah membentuk manusia Indonesia Pancasila yang fisik kuat-sehat berprestasi tinggi, memiliki kemampuan mental dan ketrampilan kerja yang kritis kreatif dan sejahtera. Jadi olahraga ialah suatu usaha mendorong, membangkitkan, dan membina kekuatan jasmaniah maupun rokhaniah pada tiap manusia. Olahraga untuk mempertahankan existensi kemanusiaan dan untuk melakukan cita-cita hidup bangsa. Olahraga merupakan pembentukan fisik dan mental (Utvi Hinda Zhannisa, 2015: 866). 
Beberapa manfaat olahraga panahan pada kesehatan adalah sebagai berikut:

\section{Peningkatan Kesehatan Jantung}

Pengerahan tenaga fisik yang diperlukan untuk menembakkan busur meningkatkan detak jantung, seperti halnya berjalan ke dan dari target saat mengambil anak panah. Hal ini membuat darah memompa dan membakar kalori, sama seperti bentuk olahraga lainnya.

\section{Penguatan Otot}

Kelompok otot bahu, punggung, dada, lengan, dan otot inti bekerja aktif saat menembakkan busur. Anak panah yang dilesatkan dilakukan secara berulang-ulang dalam olahraga panahan.

\section{Penghilang Stres}

Memanah adalah cara yang bagus untuk mengeluarkan tenaga dan menghilangkan banyak stres individu dari hari ke hari, atau mingguan. Orang yang membidik sasaran, dan anak panahnya mencap di titik pusat sasaran, akan memberikan kegembiraan tersendiri.

\section{Peningkatan Koordinasi Tangan-Mata}

Keberhasilan seorang pemanah sangat bergantung pada tingkat koordinasi tanganmata. Saat menembakkan busur, pikiran pemanah harus dapat menyampaikan pesan ke otak. Melalui latihan yang berkelanjutan, koordinasi tangan-mata seorang pemanah terus meningkat, dan pemanah memperoleh kemampuan untuk bereaksi secara fisik lebih cepat terhadap rangsangan visual.

\section{Modern Mississauga (2020: 1)}

Model konseptual hubungan olahraga-nilai dapat terlihat melalui program pendidikan lewat gerak atau bermain (play) dan olahraga (sport). Di dalamnya terkandung arti bahwa gerakan, permainan, atau cabang olahraga tertentu yang dipilih hanya alat untuk mendidik. Aktivitas olahraga yang syarat dengan nilai-nilai mempengaruhi sistem nilai yang dimiliki individu. Sistem nilai yang dimiliki individu mempengaruhi tingkah laku.

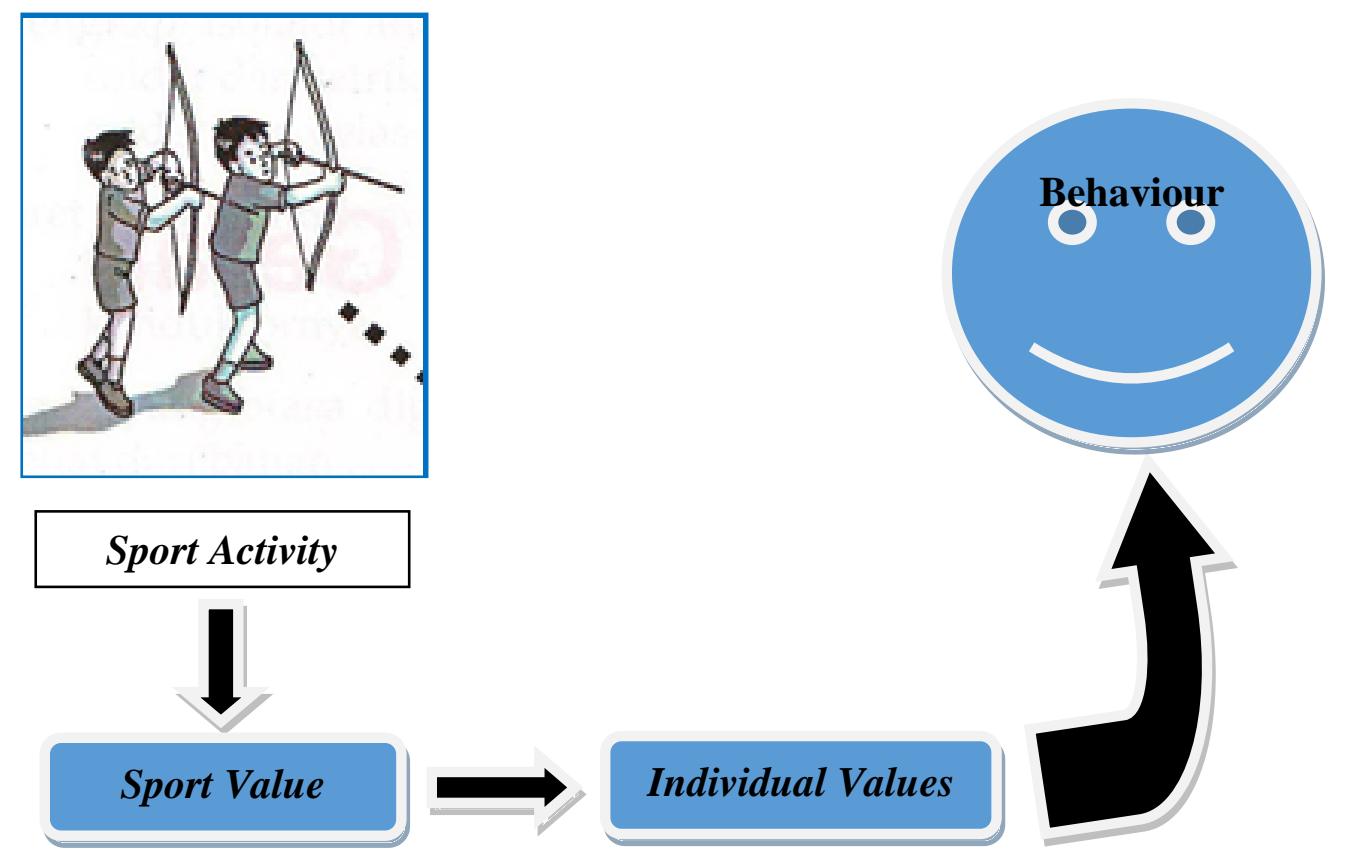

Gambar 1. Model Konseptual Hubungan Olahraga-Nilai

(Tim Peneliti Balitbang Diknas, 2008 dalam Bafirman) 


\section{METODE}

Penelitian yang dilakukan adalah penelitian campuran (mixed methods). Penelitian ini dilaksanakan di Wilayah Sleman Barat. Pelaksanaan olahraga panahan yang dilakukan selama 24 kali pertemuan, selama 8 minggu, dengan memberikan teknik dasar panahan.

Metode pengumpulan data yang digunakan adalah dengan observasi, wawancara yang mendalam, dokumentasi untuk mendapatkan data nilai-nilai Pancasila dalam olahraga panahan, dan angket untuk melihat respons imunitas tubuh. Sampel yang digunakan pada penelitian berjumlah 50 orang diambil secara purposive sampling dengan kriteria laki-laki dan perempuan terdaftar di Klub Panahan di Wilayah Sleman Barat, serta bersedia untuk melakukan olahraga panahan yang dibimbing oleh Pelatih yang professional. Uji coba instrumen untuk menguji kesahihan butir dengan bantuan komputer Program SPSS. Analisis data pada data kuantitatif menggunakan persentase untuk mengetahui respon imunitas tubuh, dan teknik analisis data kualitatif menggunakan analisis interaktif.

\section{HASIL DAN PEMBAHASAN}

COVID-19 memiliki efek menghancurkan pada komunitas secara global, yang menyebabkan pembatasan signifikan pada semua sektor masyarakat, termasuk olahraga. Pada masa pandemi COVID-19, olahraga memiliki peran penting dalam memulihkan normalitas. Organisasi olahraga dan atlet akan dihadapkan pada keputusan yang kompleks mengenai kelanjutan kegiatan pelatihan dalam keadaan saat ini. Prioritas utama untuk olahraga harus memastikan bahwa kembali beraktivitas tidak membahayakan kesehatan masyarakat. Prinsip-prinsip yang dilakukan berlaku untuk olahraga individu pasif (nonkontak) seperti: olahraga bersepeda, golf, panahan (Hughes David et al, 2020: 639). Olahraga panahan yang tidak terjadi kontak dengan orang lain, memberikan kemudahan khususnya pada penerapan protokoler kesehatan di masa pandemi COVID-19.

Pandemi COVID-19 telah menimbulkan banyak pertanyaan tentang bagaimana kita dapat meningkatkan kekebalan melalui olahraga. Belum ada data ilmiah yang kuat tentang bagaimana aktivitas fisik dapat meningkatkan respons imun terhadap virus corona, tetapi diketahui bersama bahwa peningkatan kebugaran kardiorespirasi dan olahraga pada intensitas sedang dapat meningkatkan respons imun terhadap vaksinasi, mengurangi peradangan kronis tingkat rendah, dan memperbaiki berbagai penyakit. Data epidemiologi menunjukkan bahwa orang yang aktif secara fisik cenderung tidak melaporkan gejala penyakit pernapasan bagian atas dan ada bukti bahwa olahraga dapat melindungi inang dari berbagai jenis infeksi virus termasuk influenza, rhinovirus (penyebab lain dari flu biasa) dan pengaktifan kembali laten (Simpson 2 2020: 6).

Pada penelitian ini, karakteristik responden berdasarkan jenis kelamin dapat dilihat pada tabel berikut.

Tabel 1. Jenis Kelamin

\begin{tabular}{lll}
\hline Jenis Kelamin & Jumlah & Persentase \\
\hline Laki-laki & 22 & $44 \%$ \\
Perempuan & 28 & $56 \%$ \\
\hline Total & 50 & $100 \%$ \\
\hline
\end{tabular}

Exercises dengan intensitas sedang dalam rangka: (1) meningkatkan hormon endorfin dalam menekan hormon stres, mengurangi nyeri inflamasi, (2) meningkatkan fungsi microbial killing, (3) meningkatkan antibodi dan sel imunitas tubuh dan (4) menjaga kekuatan otot, integritas saraf, tulang dan sendi, serta (5) meningkatkan performa lung capacity (Arisandy Achmad, 2020: 1). Virus korona yang mengakibatkan infeksi pernapasan COVID-19 yang sering disebut sebagai SARS-CoV-2 dapat langsung 
menyerang sistem saraf pusat. Karantina yang digunakan untuk mencegah penyebaran SARS-CoV-2 dengan mudah dapat menyebabkan depresi, yang berdampak negatif pada Sistem Saraf Pusat (SSP) dan sistem kekebalan tubuh. Olahraga teratur dengan intensitas sedang membatasi efek berbahaya terkait karantina pada otak. Olahraga panahan dengan intensitas sedang sangat tepat dilakukan bagi anak-anak yaitu memanah dengan jarak $15 \mathrm{~m}$, $20 \mathrm{~m}, 25 \mathrm{~m}$, durasi 60 sampai dengan 70 menit, dan dilakukan secara berulang-ulang dalam bentuk rambahan, frekuensi 3 kali per minggu.

Tabel 2. Nilai Total Skor Respon Imun

\begin{tabular}{lll}
\hline Kategori & Jumlah & Persentase \\
\hline Buruk & - & $0 \%$ \\
Cukup & 2 & $4 \%$ \\
Baik & 48 & $96 \%$ \\
\hline Total & 50 & $100 \%$ \\
\hline
\end{tabular}

Berdasarkan tabel di atas, data skor respon imun anak-anak yang aktif mengikuti olahraga panahan, menunjukkan bahwa $96 \%$ pada kategori baik, dan $4 \%$ masuk kategori cukup. Hal ini membuktikan anak-anak yang melakukan olahraga panahan dengan intensitas sedang di lapangan terbuka secara teratur memiliki imun yang baik, sehingga tubuh terasa bugar dan tidak mengalami stres. Keadaan seperti ini memberikan keuntungan bagi anakanak, karena selain dapat menikmati olahraga panahan juga mendapatkan manfaat kesehatan.

Olahraga sangat penting untuk kesehatan jantung dan dianggap penting selama pandemi COVID-19. Bagian dari strategi untuk mengurangi penyebaran virus adalah melalui isolasi sosial, tetapi isolasi sosial berisiko mengurangi aktifitas fisik dengan potensi konsekuensi jangka panjang. Rekomendasi untuk orang yang sehat selama dan setelah pandemi COVID-19 adalah tetap aktif secara fisik dan berolahraga sambil menjaga jarak secara sosial (Woods Jeffrey A, 2020: 58). Olahraga panahan pada masa pandemi COVID19 menjadi pilihan bagi anak-anak untuk bergerak aktif dalam mengisi waktu luang.

Berdasarkan pengambilan data kualitatif yang di dapatkan, maka nilai-nilai Pancasila dapat tercermin dalam olahraga panahan sebagai berikut:

\section{Nilai Ketuhanan}

Nilai Ketuhanan Yang Maha Esa mengandung arti bahwa adanya pengakuan dan keyakinan bangsa terhadap adanya tuhan sebagai pencipta alam semesta. Dari nilai tersebut, menyatakan bahwa bangsa Indonesia adalah bangsa yang religius, bukan bangsa yang tidak memiliki agama atau ateis.

Penjelasan oleh Fauzan saat wawancara yang didapatkan adalah sebagai berikut: "dengan kepercayaan seorang pemanah terhadap adanya Tuhan, maka seorang pemanah selalu berdoa memohon sebelum melakukan olahraga memanah agar dapat diberi kelancaran, serta diakhir memanah selalu mengucap syukur atas manfaat yang diperoleh".

\section{Nilai Kemanusiaan}

Nilai kemanusiaan yang adil dan beradab ini mengandung arti kesadaran sikap dan perilaku sesuai dengan nilai-nilai moral dalam kehidupan bersama atas dasar tuntutan hati nurani dengan memperlakukan suatu hal sebagaimana mestinya.

Kaitannya dengan olahraga panahan, setiap pemanah harus mampu menerapkan sikap dan perilaku yang sesuai dengan nilai-nilai moral yang berlaku di dalam aturan panahan. Hal ini seperti yang disampaikan oleh Shakyla saat wawancara bahwa: "pemanah harus satu garis di shooting line, dalam menarik busur yang sudah ada anak panahnya tidak boleh saling berhadap-hadapan, karena ketika busur ditarik berhadapan akan membahayakan pemanah lain". 


\section{Nilai Persatuan}

Nilai persatuan Indonesia mengandung makna usaha kearah untuk bersatu dalam kebutuhan rakyat untuk membina rasa nasionalisme dalam Negara Kesatuan Republik Indonesia.

Penjelasan ini disampaikan oleh Adhi saat wawancara, yaitu sebagai berikut: "para pemanah di bagian beregu, harus bahu membahu untuk mendapatkan skor yang tertinggi, walaupun salah satu anggota dalam memanah mempunyai kekurangan. Dari bahu membahu tersebut akan semakin timbul rasa persatuan dan kesatuan sesama pemanah".

\section{Nilai Kerakyatan}

Nilai kerakyatan disini harus dimiliki oleh setiap elemen petinggi Negara Indonesia. Dengan mengutamakan kepentingan Negara dan masyarakat dengan cara mufakat atau musyawarah.

Ketika di lakukan wawancara, Arfa menjelaskan bahwa: "dalam olahraga panahan, hasil tembakan pada face target berupa skor. Tancapan anak panah apabila masuk garis, maka akan dihitung skor yang lebih tinggi. Apabila terjadi keraguan, maka pemanah dapat menyampaikan ke pelatih, kemudian ke wasit yang merupakan elemen tertinggi”.

\section{Nilai Keadilan}

Nilai keadilan merupakan nilai yang sangat mendasar yang dihadapkan dari seluruh bangsa Indonesia yaitu keadilan bagi seluruh rakyat Indonesia.

Pendapat tentang keadilan yang disampaikan oleh Arkan ketika wawancara yaitu: "pemanah yang melesatkan anak panah di bagi dalam beberapa rambahan. Pada rambahan I dimulai dari pemanah $\mathrm{AB}$ terlebih dahulu yang memanah, selanjutnya diikuti oleh pemanah CD. Masuk pada rambahan II dimulai pemanah CD yang memanah, selanjutnya diikuti oleh pemanah AB. Hal ini dilakukan secara adil dengan waktu yang disediakan sama untuk masing-masing pemanah, sehingga terlihat jelas pada nilai keadilan”.

\section{SIMPULAN}

Olahraga panahan memiliki manfaat kesehatan yang banyak seperti: peningkatan kesehatan jantung, penguatan otot, penghilang stres, dan koordinasi mata-tangan. Olahraga panahan yang dilakukan di ruang terbuka dengan terik sinar matahari mengenai tubuh pemanah memberikan peningkatan imun di masa pandemi Covid-19. Untuk dapat melakukan olahraga panahan dengan aman, maka pemanah harus mengikuti protokol kesehatan seperti: cuci tangan, memakai masker, menjaga jarak antar pemanah, dan menggunakan peralatan busur beserta aksesorisnya masing-masing. Nilai-nilai Pancasila yang terkandung dalam implementasi olahraga panahan memberikan manfaat tersendiri dengan cara para Pelatih memberikan contoh-contoh tindakan yang nyata di lapangan sesuai dari masing-masing Sila Pancasila, sehingga manfaat yang diperoleh dari anak-anak melakukan olahraga panahan yaitu beriringan terbangunnya imunitas tubuh yang baik, dan pemahaman tentang Nilai-nilai Pancasila semakin lebih kuat.

\section{DAFTAR PUSTAKA}

Arisandy Achmad, Kasim Nurhas Jaiddin, Sulfandi, Neti Eka Jayanti, Rezky Amaliah Usman. (2020). Manfaat Exercises Intensitas Sedang Dalam Menjaga Imunitas Tubuh Di Masa Psbb Pandemi Covid-19 Selama Di Rumah Aja. Jurnal Abdimas Medika, Vol 1 No 2 (2020). 
Bafirman. (2012). Implementasi Pendidikan Karakter Melalui Pembelajaran Pendidikan Jasmani Olahraga dan Kesehatan. Padang: SUKABINA PRESS.

Hughes David, Saw Richard, Perera Nirmala Kanthi Panagodage Perera, Mathew Mooney, Wallett Alice, Cooke Jennifer, Coatsworth Nick, Broderick Carolyn. (2020). The Australian Institute of Sport framework for rebooting sport in a COVID-19 environment. Journal of Science and Medicine in Sport, Volume 23, Issue 7, July 2020, Pages 639-663, https://doi.org/10.1016/j.jsams.2020.05.004.

Kaur Harleen, Tushar Singh, Yogesh K. Arya and Shalin Mittal. (2020). Physical Fitness and Exercise during COVID-19 Pandemic: A Qualitative Enquiry. Psychol. | doi: 10.3389/fpsyg.2020.590172.

Modern Mississauga. (2020). The Health Benefits of Archery. Interactive Magazine, July 02, 2020 .

Prosiding Kongres Pancasila IV. (2012). Strategi Pelembagaan Nilai-nilai Pancasila dalam Menegakkan Konstitusionalitas Indonesia, Yogyakarta 31 Mei - 01 Juni 2012. PSP UGM.

Ratnasari Putri Utami, Koentjoro. (2018). Mindfulness in Relation to the Meaning of Life of Jemparingan(Mataraman traditional Archery) in the Perspective of Kawruh Jiwa Ki Ageng Suryomentaram. INTERNATIONAL JOURNAL OF ENVIRONMENTAL \& SCIENCE EDUCATION, e-ISSN: 1306-30652018, Vol. 13, No. 6, 551-557.

Simpson Richard J. and Katsanis Emmanuel. (2020). The Immunological Case for Staying Active During the COVID-19 Pandemic. Brain Behav Immun. 2020 Jul; 87: 6-7. doi: 10.1016/j.bbi.2020.04.041.

Suryo Ediyono. (2016). PSHT Logo as Manifestation of Pancasila Ideological Values. International Journal of Indonesian Society And Culture, Komunitas 8 (2) (2016): 309-318 DOI:10.15294/komunitas.v8i2.7322.

Sutan Syahrir Zabda. (2016). Aktualisasi Nilai-nilai Pancasila sebagai Dasar Falsafah Negara dan Implementasinya Dalam Pembangunan Karater Bangsa. Jurnal Pendidikan Ilmu Sosial, Vol 26, No.2, Desember 2016, ISSN: 1412-3835.

Utvi Hinda Zhannisa. (2015). Implementasi Nilai-nilai Olahraga dalam Pembangunan Nilai Kewarganegaraan dan Memperkokoh NKRI. Jurnal Ilmiah CIVIS, Volume V, No 2, Juli 2015.

Woods Jeffrey A. , Hutchinson Noah T. , Powers Scott K. , Roberts William O., Cabrera Mari Carmen Gomez, Radak Zsolt, Berkes Istvan, Boros Anita, Boldogh Istvan, Leeuwenburgh Christiaan, Júnior Hélio José Coelho, Marzetti Emanuele, Cheng Ying, Liu Jiankang, Durstine J. Larry, Sun Junzhi , and Ji Li Li. (2020). The COVID-19 Pandemic and Physical Activity. Sports Medicine and Health Science. 2020 Jun; 2(2): 55-64. Published online 2020 May 30. doi: 10.1016/j.smhs.2020.05.006. 